\title{
Kapsayıcı Liderlik Ölçeğinin Türkçe Uyarlaması ve Kapsayıcı Liderliğin İş Performansı Üzerindeki Etkisinde Psikolojik Güvenliğin Aracılık Rolü ${ }^{1}$
}

\author{
Turkish Adaptation of the Inclusive Leadership Scale and the Mediating Role of \\ Psychological Safety in the Impact of Inclusive Leadership on Job Performance
}

\author{
Emre $G \ddot{U} L^{*}$ \\ Ahmet Burhan ÇAKICI **
}

$\ddot{O} Z$

Bu çalışmanın amacı, Carmeli ve diğ. (2010) tarafından geliştirilen Kapsayıcı Liderlik Ölçeğinin Türkçe’ ye uyarlanması ve kapsayıcı liderlik ile iş performansı arasındaki ilişkide psikolojik güvenliğin aracılık rolünün incelenmesidir. Oluşturulan model ve hipotezlerin testinde birinci örneklem için 136 sağlık çalışanından, ikinci örneklem için Türkiye' de bir devlet üniversitesinde çalışan 350 akademik personelden anket tekniğiyle veriler toplanmiştır. Veriler SPSS ve AMOS programları kullanılarak analiz edilmiştir. Birinci örneklem için yapılan analizler sonucunda Kapsayıcı Liderlik Ölçeğinin tek faktörlü yapıya uyum sağladı̆̆ görülmüşürr. İkinci örneklem için yapılan analizler neticesinde kapsayıcı liderliğin iş performansı ve psikolojik güvenlik üzerinde olumlu bir etkisinin olduğu ve kapsayıcı liderlik ile iş performansı arasındaki ilişkide psikolojik güvenliğin kısmi aracı etkisinin bulunduğu tespit edilmiştir.

ANAHTAR KELIMELER

Kapsayıcı Liderlik, İs Performansı, Psikolojik Güvenlik

\begin{abstract}
The purpose of this study is to adapt the Inclusive Leadership Scale developed by Carmeli et al. (2010) into Turkish and to examine the mediating role of psychological safety on the relationship between inclusive leadership and job performance. To test the model and hypotheses created, from 136 health employees for the first sample, for the second sample data were gathered through a survey conducted from 350 academic staff working in a state university in Turkey. The data were analyzed using SPSS and AMOS programs. As a result of the analysis made for the first sample, it was seen that the Inclusive Leadership Scale was adapted to a single factor structure. As a result of the analysis for the second sample, it is found that inclusive leadership has a positive effect on job performance and psychological safety, and psychological safety has a partial mediator effect on the relationship between inclusive leadership and job performance.
\end{abstract}

\section{KEYWORDS}

Inclusive Leadership, Job Performance, Psychological Safety

\begin{tabular}{|c|l|c|}
\hline \multicolumn{3}{|c|}{ Makale Geliş Tarihi / Submission Date } \\
12.03.2021
\end{tabular}

\footnotetext{
${ }^{1}$ Bu çalışma, "Kapsayıcı Liderliğin İş Performansı Üzerindeki Etkisinde Psikolojik Güvenliğin Aracılık Rolü” adlı yüksek lisans tezinden üretilmiştir.

* Öğr. Gör., Erzincan Binali Yıldırım Üniversitesi Meslek Yüksekokulu, emre.gul@erzincan.edu.tr, ORCID: 0000-0003-4884-3974

** Doç. Dr., Karamanoğlu Mehmetbey Üniversitesi İşletme Bölümü, ahmetburhan@kmu.edu.tr, ORCID: 0000-0003-4848-3278
} 


\section{GİRIŞ}

Lider kavramı, geçmişten günümüze kadar günlük hayatta sıklıkla kullanılan kavramlardan biridir. Bilimsel literatürde son dönemlerde liderlik konuları üzerine artan bir ilginin olduğu söylenebilir. Her örgüt içerisinde liderler önemli bir yere sahiptir ve örgütler faaliyetlerini sürdürürken liderlerine ciddi oranda ihtiyaç duymaktadırlar. Liderlik ile yöneticilik birbirinden farklı kavramlardır. Liderler çalışanlara ilham vererek onları değişim yönünde olumlu etkileyen, yaratıcı fikirler sunan, vizyon sahibi ve örgütü istenilen performans düzeyine ulaştıran kişilerdir. Yöneticiler ise daha çok çalışanlara motivasyon düzeyinde yardımcı olan, genellikle yapı üstünde çalışan ve çok fazla yenilikçi olmayan kişilerdir. Bu nedenle örgüt içerisinde yöneticilerden ziyade liderlerin varlığı kuruluşun gelişimi açısından son derece önemlidir.

$\mathrm{Bu}$ yönüyle karşımıza birtakım liderlik stilleri çıkmaktadır. Kapsayıcı liderlik bu liderlik tarzlarından biridir. Kapsayıcı lider, örgüt hedefleri doğrultusunda çalışanlardan gelebilecek yeni fikir ve önerilere açıktır. Çalışanlar lidere bir şey danışmak istediğinde ulaşılabilirdir. Kapsayıcı liderler, herhangi bir problem ya da sorun olduğu zamanlarda uygundurlar (Carmeli ve diğ., 2010:250-252). Kapsayıcı liderlik, çalışanların kendilerini örgütün bir parçası gibi hissetmelerini sağlayarak onlar üzerinde bir güven algısı oluşturmaktadır. Kapsayıcı lider, çalışanlara enerji ve motivasyon sağladığından dolayı, çalışanlar kendilerini saygın ve değerli hissederler ve ortak hedeflere ulaşma yolunda ekstra performans ortaya koyarlar (Gündüzöz, 2013:185). Kapsayıcı liderlik, örgüt için önemli kararların alınmasında ve hedeflenen sonuçları elde etmekte oldukça başarılıdır. Ayrıca çalışanların birbirleriyle olan ilişkilerini teşvik ederek hem liderlere hem de çalışanlara fayda sağlamaktadır. Geleneksel liderlik perspektifinde liderlerin; karizmalarına, yeteneklerine, niteliklerine ve karakterlerine daha fazla önem verilirken çalışanlarla sürdürülebilir ve etkin bir iletişim ortamı oluşturma eğilimine dikkat edilmemektedir. Bu nedenle kapsayıcı liderlik, geleneksel liderlik anlayışının sınırlarını aşmaktadır. Herkesin faydasına olacak mekanizmalar oluşturup, mevcut sürece çalışanları da dahil ederek terimi bir üst düzeye taşımaktadır (Adapa ve Sheridan, 2018:68).

Psikolojik güvenlik algısı literatürde son yıllarda yaygın olarak ele alınan konulardan biridir. Psikolojik güvenlik, çalışanın kişilerarası riskler alma konusunda kendini rahat hissetme derecesi olarak ifade edilmektedir. Psikolojik güvenlik algısına sahip çalışanlar, çalışma ortamındaki diğer çalışanlardan gelebilecek olumsuz davranışlardan korkmadan örgüt için faydalı olabilecek davranışlar sergilerler. Psikolojik güvenliğin örgütte var olması; çalışanların birbirleriyle işbirliği yapmasına, ortak hedefe ulaşmak için yapıcı çalışmaların yapılmasına, çalışanların fikir ve düşüncelerini rahatça dile getirebilmelerine ve çalışanların risk alırken kaygı yaşamamalarına zemin hazırlamaktadır. Dolayısıyla psikolojik güvenliğin ekip düzeyinde bir yapı olduğu ve performans arttırıcı sonuçlarının olabileceği ifade edilmektedir (Edmondson, 1999:350).

İş performansı literatürde sıkça çalışılan kavramlardan biridir. İş performansı genellikle bir örgütün belirlenen amaç ve hedeflerine katkı sağlayan eylem veya davranışlar olarak ifade edilmektedir (Rotundo ve Sackett, 2002:66). Dolayısıyla bir örgütün başarıya ulaşması çalışanların ortaya koydukları performans ile doğru orantılıdır. Bu yüzden çalışanların performans düzeylerini arttırmak örgütler için oldukça önemli bir konudur. Örgütler birtakım stratejiler geliştirerek çalışanların performanslarını arttırmaya çalışırlar. Yöneticilerin sergilediği tutum ve davranışlar, çalışan performansı üzerinde etkili olan bir faktördür. Çalışanlar tarafından benimsenen bir lider örgüt içerisinde olumlu etkiler meydana getirir. Bu olumlu hava da çalışan performansinın artmasinı beraberinde getirmektedir.

$\mathrm{Bu}$ çalışma ile literatüre birtakım katkılar sağlanması beklenmektedir. İlk olarak Carmeli ve diğ. (2010) tarafından geliştirilmiş olan Kapsayıcı Liderlik Ölçeğinin Türkçe uyarlaması yapılarak, Türkçe alanyazında kullanılıp kullanılamayacağının belirlenmesidir. İkinci olarak, örgütler için büyük bir öneme sahip olan iş performansı ve psikolojik güvenlik kavramlarının ele alınması ve kapsayıcı liderliğin iş performansı ve psikolojik güvenlik kavramlarına etkisinin incelenmesidir. Son katkı ise, kapsayıcı liderliğin çalışanların iş performansı üzerindeki etkisinde psikolojik güvenliğin aracılık etkisinin ele alınmasıdır. Literatür incelemesi sonucunda kapsayıcı liderlik, psikolojik güvenlik ve iş performansını birlikte inceleyen hiçbir araştırmaya ulaşılamamıştır. Bu çalışmanın; kapsayıcı liderlik ile iş performansı arasındaki ilişkide psikolojik güvenliğin aracılık etkisinin inceleneceği ilk araştırma olması açısından liderlik literatürüne faydalı bir kuramsal katk1 sağlaması öngörülmektedir.

\section{KURAMSAL ÇERÇEVE}

\subsection{Kapsayıcı Liderlik Kavramı}

Kapsayıcı Liderliğin nispeten yeni bir çalışma alanı olduğu düşünüldüğünde, literatürde tanımlanma biçiminde önemli farklılıklar vardır. Nembhard ve Edmondson (2006) tarafından ilk kez Kapsayıcı Liderlik kavramı, liderin kapsayıcılığı olarak ortaya atılmıştır. Nembhard ve Edmondson kapsayıcı liderliği, bir liderin 
veya liderlerin başkalarının katkıları için bir davet ve takdiri belirten kelimeler ve eylemler olarak tanımlamışlardır (Nembhard ve Edmondson, 2006:947). Lirio ve diğ. (2008) çalışanların örgüte aidiyet hissi beslemeleri ve kapsayıcı davranışlar sergilemelerinin örgütteki gündelik hayatı temsil ettiğini belirtmişlerdir (Lirio ve diğ., 2008:443). Carmeli ve diğ . (2010) kapsayıcı liderleri, insanların genellikle normlarla senkronize olamayan fikirleri ifade etmek için; psikolojik olarak güvenli olan bir bağlam oluşturarak yeni fikirler ortaya koyan, çalışanlara karşı açık, ulaşılabilir ve erişilebilir olan bir lider olarak tanımlamıştır (Carmeli ve diğ., 2010:250). Kapsayıcı liderlik, liderlerin takipçilerinin ihtiyaçlarına ve onlara ulaşılabilirliğine açık bir şekilde dikkat çeken bir ilişkisel liderlik modu olarak görülmüştür (Hollander, 2009:4). Randel ve diğ. (2018), Kapsayıcı Liderliğin diğer liderlik teorilerinden farklı olarak kendi çerçevesi bağlamında düşünülmesi gerektiğini öne sürmüşlerdir. En güncel ve kapsamlı literatür taramasında, gelecekteki araştırmalara rehberlik etmek ve ortak bir zemin oluşturmak için teorik olarak temellendirilmiş bir model önermektedirler. Sosyal kimlik teorisi ve en iyi ayırt edici teori üzerine dayanarak kapsayıcı liderliği; çalışanların, kendilerini örgütün bir parçası olarak hissetme (aidiyet), grup süreçlerine ve sonuçlarına katkıda bulunurken bireyselliklerini korumaya odaklanan bir dizi lider davranışı olarak tanımlamaktadırlar (Randel ve diğ., 2018:191).

Hollander ve diğ. (2008) liderlik ve takipçiliğin işleyişinin her iki şekilde de saygı, tanınma, duyarlılık ve sorumluluğa bağlı olduğunu araştırmaktadır. Bunlar, başarılı bir uygulama için hayati önem taşıyan kapsayıcı liderliğin dört bileşenidir. İşlevsel olarak kapsayıcı liderlik; çeşitli ekipler oluşturma, krizleri tedavi etme, değişimi yönetme, eşitsizlikleri ve baskıları ele alma gibi bir lider tarafından her gün yapılan faaliyetlerde yönlendirilen bir eylemdir (Hollander ve diğ., 2008:4). Kapsayıcı liderlik, bireylerin işe entegre edilmesi ile de ilgilidir. Sosyal değişim teorisine göre, çalışanlar tarafından erişilebilir ve açık olan kapsayıcı liderler çalışanlara daha yararlı çıktılar sağlamaktadır. Liderlerden gelen yararlı çıktılar, çalışanları daha fazla teşvik eder ve onların kendilerini önemli hissetmelerine imkan sağlar. Ayrıca, çalışanlara karşı uygun, açık ve erişilebilir olan kapsayıcı liderler takipçilerinin motivasyonlarını olumlu yönde etkilemektedirler (Choi ve diğ., 2015:934).

Liderlik kavramı, daha önce kabul edilmiş çalışma ve etkileşim yollarını incelemek, bu doğrultuda kimin ve neyin makul olarak görüldüğü hususunda yeniden değerlendirme yapmak için süregelen karmaşık bir süreçtir (Ferdman, 2014:12-13). Kapsayıcı liderler, yaşam boyu öğrenenler olmalıdır. Özellikle gruplar arası tutum ve davranışlarla ilgili olarak sürekli öğrenmeye istekli olmalı ve daima kendi gelişimlerine odaklanmalıdırlar. Kapsayıcı liderler, çoğu zaman bilmedikleri ve hata yapacakları gerçeğine teslim olarak bir öğrenme duruşu sergilerler. Liderler farklılıkların sınırlarını aştıkça; sosyal kimliklerin, grup içi kimliklerin, çatışmaların, çeşitliliğin, sosyal ve yasal görüşlerin rolünün bilincinde olmalıdırlar (Wasserman ve diğ., 2008:186-187). Liderler, çalışanların kişiliklerine saygı gösterirken, örgütteki problemlerle mücadele etmek için sosyo-tarihsel önyargıların ve belirli sosyal kimliklerin marjinalleşmesinin de farkında olmalıdırlar. Kapsayıcı liderler, tam katılımın teşvik edildiği, farklı grupların iktidar ve karar alma süreçlerine eşit erişime sahip olduğu ve gerçek diyalogun gerçekleşmesi için güvenli alanın sağlandığı bir iklim yaratmaya çalışırlar. Kapsayıcı liderler, başkalarının bakış açılarını takdir etmeyi ve bu bakış açılarını önemli olarak görmeye istekli oldukları konusunda çalışanları teşvik etmektedirler (Chrobot-Mason ve dĭg., 2014:693-694).

Bir kuruluşa liderlik etmek; o kuruluşun stratejisini, yapısını, kurallarını ve prosedürlerini iyi bilmekten geçmektedir (Chrobot-Mason ve diğ., 2014:697). Kapsayıcı liderliğin örgütsel düzeyi için önemli konulardan biri, değişime öncülük edebilmektir (Booysen, 2014:307). Varsayımlar, değerler ve inançlar; örgütün yapıs1, kültürü, sistemleri, stratejileri ve uygulaması boyunca değerlendirilmelidir. Kuruluşların çeşitlilikten yararlanmak için mevcut kültürleri üzerinde düşünebilmeleri gerekmektedir (Gallegos, 2014:189). Diğer örgütlerde olduğu gibi kapsayıcı örgütlerde de normlar ve sınırlar sürekli olarak yeniden değerlendirilmeli ve liderlerin değişim için gerekli kapasite ihtiyaçları ele alınmalıdır. Çalışanların, örgüt içinde birbirleriyle etkileşim kurma biçimlerini değiştiren yapısal bir dönüşüm mekanizması oluşturulmalıdır (Wasserman ve diğ., 2008:180). Değişimin yanı sıra kapsayıcı liderler çatışma ve direnişle de başa çıkabilmelidir. Kuruluş içerisinde ortak bir amaca hizmet etmek, çalışma grubu içinde sosyal olarak inşa edildiğinden ve çalışma grubu iklimi sosyal etkileşimler yoluyla öğrenildiğinden, çalışma grubu üyeleri işyerinde etkileşimler ve davranışlar anlamında liderlere güvenme eğilimindedir. Bu nedenle kapsayıcı liderlerin, çalışan algılarının şekillenmesine yardımcı olmak için temel işlevlerinden biri, birliktelik ortamı inşa edilmesine yardımcı olmaktır (Boekhorst, 2015:245).

Booysen' e göre (2014) liderlik gelişiminin kapsayıcı olması için bireysel (mikro), grupsal (meso) ve örgütsel (makro) gelişim düzeylerinin göz önünde bulundurması gerekmektedir. Kapsayıcı liderlik gelişimi için bir düşünce yaklaşım sisteminin gerekli olduğuna inanmaktadır. Örgütsel düzeyde liderliğin, kapsayıcı bir örgüt kültürü meydana getirmekle ilgili oluğunu, grupsal düzeyde kapsayıcı liderliğin diyalog ile mümkün 
olduğunu ve bireysel düzeyin ise bireysel liderlerin kişilerarası ve içsel gelişimiyle ilgili olabileceğini öne sürmüştür (Booysen, 2014:297). Wuffli (2016) yaptığı bir çalışmasında kapsayıcı liderlik için yeni bir çerçeve oluştururken; dinamizm ve değişim odaklılık, yatay olarak kültürler ve toplumun farklı kesimleri arasında köprü inşa etmek, bütünsel ve geniş kapsamda olabildiğince fazla insanı ve çeşitli durumları entegre etmek ve açıkça normatif olmak üzere dört yol gösterici ilke önermiştir (Wuffli, 2016:3-4).

Choi ve di ̆. (2015), kapsayıcı liderliğin çalışanın işe adanmışlığı ile olumlu ilişkili olduğu ve hem duygusal örgütsel bağlılığın hem de çalışan yaratıcılığının bu ilişkiye aracilık ettiği sonucuna ulaşmışlardır (Choi ve diğ., 2015:931). Wang ve diğ . (2019), kapsayıcı liderliğin, yenilikçi davranış ve işe adanmışlık ile anlamlı ve pozitif ilişkili olduğunu ve işe adanmışlı̆ğn yenilikçi davranış ile bağlantılı olduğunu tespit etmişlerdir (Wang ve di ̆. ., 2019:688). Aslan (2019), işe adanmışlığın yenilikçi iş davranışı ve kapsayıcı liderlik üzerinde pozitif ve anlamlı ilişkili, kapsayıcı liderliğin yenilikçi iş davranışı üzerinde olumlu ve anlamlı ilişkili olduğunu tespit etmiştir (Aslan, 2019:1055). Khan ve diğ. (2020), kapsayıcı liderlik ile proje başarısı arasında pozitif bir ilişki olduğunu, kapsayıcı liderliğin psikolojik güçlendirme ve psikolojik güvenliğin aracılık rolleri yoluyla hem doğrudan hem de dolaylı olarak proje başarısını arttırdığını tespit etmişlerdir (Khan ve diğ., 2020:1077).

\section{2. İş Performansı Kavramı}

Uzun yıllar araştırmacılar, çalışan performansı yapısının boyutsallığını anlamaya ve ortak bir ölçüm çerçevesi bulmaya çalışmışlardır. İş performansı, genellikle bir örgütün amaçlarına katkıda bulunan eylemler ve davranışlar olarak tanımlanmaktadır (Rotundo ve Sackett, 2002:66). Motowidlo ve diğ. (1997), iş performansını bir bireyin standart bir zaman aralığında gerçekleştirdiği ayrık davranışsal bölümlerin örgüte kattığı toplam değeri olarak tanımlamışlardır. Bazen bu ayrık davranışlar ölçülür ve daha sonra genel performans puanı oluşturmak için toplanırken bazen de çalışmalar, katılımcılardan çalışanın genel iş performansını değerlendirmelerini isteyen tek bir öğeyi içerebilmektedir (Motowidlo ve diğ., 1997:72). İş performansı, bireylerin görevleriyle ilgili rol oynamasını ve sorumluluklarını yerine getirmesini ifade etmektedir (AbuAlRub, 2004:75). Bazı araştırmacılar, iş performansı için bir model geliştirmeye çalışarak kriter sorununu ele almışlardır. Bartram (2005), işler arasında genelleştirilebilen sekiz iş yeterliliğinden oluşan hiyerarşik bir model geliştirmiştir. Modelde; kişilik özelliklerinin sekiz dar yetkinliği farklı şekilde öngördüğünü ve dar yetkinlik ölçütleri kullanmanın, genel iş performansı ölçüsünden daha yüksek eşzamanlı geçerlilikler elde ettiğini tespit etmiştir. Sonuç olarak Bartram (2005), dar ölçüt tedbirlerinin kullanılmasını savunmuştur (Bartram, 2005:1199). Tett ve Burnett (2003) kişilik özelliklerine dayalı etkileşimci bir iş performansı modeli sunmuş ve hem kişilik hem de iş performansına özgüllük uygulandığında eşzamanlı geçerliliklerin arttığını göstermişlerdir (Tett ve Burnett, 2003:500). İş performansındaki değişimlerin altında yatan süreçlerin tanımlanması, bir geçiş ve bakım adımı arasında bir ayrım gerektirebilir. Geçiş adımı, bireyler ilk kez bir iş bulduğunda ve görevler yeni olduğunda ortaya çıkmaktadır. Bakım aşaması, birisi işi yapmak için gerekli beceri ve bilgiyi öğrendiğinde ve görevi yerine getirirken otomatikman meydana gelmektedir. Geçiş aşamasında yürütme için bilişsel yeteneğe ihtiyaç duyulmaktadır. Bakım aşamasında ise değerler, motivasyon ve ilgi alanları düzeylerindeki artış gibi düzenleyici faktörleri azaltmak için bilişsel yeteneğe ihtiyaç vardır (Murphy, 1989:183-190).

\subsection{Psikolojik Güvenlik Kavramı}

Psikolojik güvenliğe ve onun organizasyonlardaki rolüne olan ilgi, 1990'lardan başlayarak günümüze kadar artarak devam etmiştir. Edmondson ve Lei (2014), psikolojik güvenlik çalışmalarının bir rönesans sürecinden geçtiğini ileri sürmüşlerdir (Edmondson ve Lei, 2014:23). Kahn (1990), psikolojik güvenliğin, insanların iş rolleriyle meşgul ve işe bağlı hissetmeleri için gerekli bir koşul olduğunu öne sürmüştür. Psikolojik güvenliği; kişinin kendi imajı, statüsü veya kariyeri üzerinde olumsuz sonuçlardan korkmadan kendini gösterebildiği ve kullanabildiği bir duygu olarak tanımlamıştır (Kahn, 1990:708). Benzer şekilde Edmondson (1999), psikolojik güvenliği, bireylerin işyerinde kişilerarası risk almanın sonuçlarına ilişkin algısı olarak tanımlamıştır. Psikolojik güvenliğin, bireylerin sorunları önlemek ve ortak bir hedefe ulaşmak için yapıcı konuşmalara odaklandığ 1 bir iklim olduğunu ifade etmiştir. Psikolojik güvenlik, bireylerin ortak bir sonuca ulaşmak için işbirliği yapma şeklini anlamada önemli bir faktördür (Edmondson, 1999:350). Psikolojik güvenlik; kişinin çalı̧̧ma ortamındaki imajı, kariyeri veya statüsü üzerinde olumsuz sonuçlardan korkmadan kişilerarası riskler alma konusunda kendini rahat hissetme derecesini ifade etmektedir. Edmondson (2003), ekip üyelerinin örgütsel bağlamlarda, özellikle de kişilerarası faaliyetlerde risk alırken kaygı yaşadıklarını açıklamaktadır. Bu tür faaliyetler arasında; yardım, geri bildirim isteme, deneme, bir hatayı bildirme veya yeni bir fikir önerme yer almaktadır (Edmondson, 2003:255). Güven ve psikolojik güvenlik ilişkili kavramlar olsa da, Edmondson (1999) psikolojik güvenliğin bir ekibi kişilerarası güvenin ötesinde etkilediğini açıklamaktadır. Spesifik olarak

Selçuk Üniversitesi Sosyal Bilimler Meslek Yüksekokulu Dergisi, Yıl: 2021 Cilt: 24 Sayı:2 
psikolojik güvenlik; her grup içinde, bir güven karışımının yokluğu veya varlığı, birbirlerinin yeterliliğine saygı ve insan olarak birbirlerini önemseme ile karakterize edilen tutarlı bir kişiler arası iklim oluşturmaktadır (Edmondson, 1999:375). Dahası, Edmondson (2003) güven ve psikolojik güvenlik arasındaki üç temel farklılıktan bahsetmektedir. Bunlar; zaman çerçevesi, odak nesnesi ve analiz seviyesidir. Psikolojik güvenlik kısa vadeli sonuçlara odaklanırken, güven geniş bir zaman çizelgesine yayılan sonuçlarla ilgilenir. Güvene odaklanmanın amacı, başkalarının davranışlarına ve doğruluğuna yönelik dışa dönük bir bakış açısı olma eğilimindeyken, psikolojik güvenlik başkalarının sizi algılama şeklini içerir. Son olarak, psikolojik güvenlik ekip düzeyinde bir yapıdır ancak güven esas olarak ikili bir ilişki içinde mevcuttur (Edmondson, 2003:258260). Psikolojik güvenlik, uygulayıcılar tarafından kolayca gözden kaçan ve performans üzerinde önemli etkisi olabilen bir yapıdır. Nembhard ve Edmondson (2006), tıbbi hatalara önemli bir rol oynayan bulunan hemşireler ve doktorlar arasındaki düşük psikolojik güvenliğin altını çizmektedir. Düşük statülü rol üyeleri; kamuoyu eleştirisi, ödül kaybı veya kötü vardiya programlarına atanma gibi olumsuz sonuçlardan korktukları için kaliteyi iyileştirici iletişime girmezler (Nembhard ve Edmondson, 2006:945).

\section{HIPOTEZLER}

\subsection{Kapsayıcı Liderlik ile İş Performansı Arasındaki İlişki}

Kapsayıcı liderlik, çalışanların beklentilerini iletmeye ve geri bildirimlerini almaya istekli olduğu bir ilişkisel liderlik biçimidir (Carmeli ve diğ., 2010:252). Bu liderlik; etik liderlik, hizmetkar liderlik ve dönüşümcü liderlik gibi diğer birkaç liderlik tarzıyla ilişkili olarak kabul edilebilir. Çünkü bir liderin destekleyici davranışları; hazır bulunuşluk, açıklık ve erişilebilirliği içeren üç yönü taşımaktadır. Kapsayıcı liderlik ayrıca, liderler ve takipçileri arasındaki pozitif bağlantı niteliklerini de motive etmektedir (Nguyen ve diğ., 2019:66). Bazı açılardan liderin kapsayıcıllğı, dönüşümcü liderlik ve etkileşimsel liderliğin bir karışımı olarak ifade edilmektedir. Her iki liderlik türü de performansı olumlu yönde etkileyebilir. Kapsayıcı liderler, çalışanları iş sürecine katkıda bulunanlar olarak algılar ve herkesin örgüt içerisinde bir değeri olduğunu kabul eder. $\mathrm{Bu}$ davranış tarzı, bireylerin işe bağlılı̆̆ını artırabilir ve işlerini esnek bir şekilde ele almalarını sağlayabilir. Ayrıca liderin kapsayıcılığı, çalışanların hedeflerinin, iş tatmin düzeylerinin ve iş performanslarının doğrudan iyileştirilmesine yönelik algılarını daha etkili bir şekilde teşvik edebilir (Carmeli ve diğ., 2010:251). Örgütsel destek teorisine göre kapsayıcı liderlik, çalışanların organizasyonda olumlu bir iş davranışı sergilemesini teşvik edebilir (Choi ve diğ., 2015:933). Kapsayıcı liderlik ile ilgili yapılan literatür incelemesi sonucunda bu kavramın genellikle işe adanmışlık, yenilikçi iş davranışı, stratejik esneklik, çeşitlilik iklimi, örgütsel vatandaşlık davranışı ve takım inovasyonu kavramları ile ilişkilendirildiği görülmüştür (Aslan, 2019; Choi ve diğ., 2015; Obaid ve Al-Abachee, 2020; Randel ve diğ., 2016; Ye ve diğ., 2019). İş performans1 ise genellikle iş stresi, dönüşümcü liderlik, duygusal zeka, etik liderlik, duygusal emek, örgütsel vatandaşlık davranışı, lider desteği, örgütsel bağl1lık ve iş tatmini kavramlarıyla ilişkilendirilmiştir (AbuAlRub, 2004; Ay ve Keleş, 2017; Ayan, 2015; Begenirbaş ve Çalışkan, 2014; Kale, 2015; Lai ve diğ., 2020; Sungu ve diğ., 2020; Van Scotter, 2000).

Yukarıda bahsedilen araştırmalardan elde edilen sonuçlara ve görüşlere dayanarak aşağıdaki hipotez geliştirilmiştir.

H1: Kapsayıcı liderlik, çalışanların iş performansını anlamlı ve pozitif yönde etkiler.

\subsection{Kapsayıcı Liderlik ile Psikolojik Güvenlik Arasındaki İlişki}

Araştırmalar, lider davranışlarının psikolojik güvenlik duygularına katkıda bulunduğunu göstermektedir (Nembhard ve Edmondson, 2006). Özellikle Edmondson (2004), liderler açıklık, hazır bulunuşluk ve erişilebilirlik tutumları sergilediğinde, işyerinde çalışanlar arasında psikolojik güvenliğin gelişimini kolaylaştıracaklarını öne sürmüş̧ür. Liderler, bu tür davranışların önemini anlatarak ve çalışanlara bu tür davranışlardan olumsuz sonuçların kaynaklanmayacağına dair güvence vererek, çalışanları yeni fikirler ortaya koyma ve risk alma konularında teşvik edebilir (Burke ve diğ., 2007). Ek olarak, yüksek kaliteli kişiler aras1 ilişkilerin psikolojik güvenliğin gelişimini kolaylaştırdığı öne sürülmüştür (Carmeli ve diğ., 2009:81). Psikolojik güvenlik ile ilgili yapılan literatür incelemesi sonucunda bu kavramın genellikle dönüşümcü liderlik, performans, kişilerarası yüksek kaliteli ilişkiler, işe adanmışlık, sosyal destek, yenilikçi iş davranışı ve çalışan sesliliği kavramları ile ilişkilendirildiği görülmüştür (Brueller ve Carmeli, 2011; Carmeli ve diğ., 2014; Carmeli ve Hoffer Gittell, 2009; Derin, 2017; Detert ve Burris, 2007; Schepers ve diğ., 2008).

Yukarıda bahsedilen araştırma sonuçları çerçevesinde kapsayıcı liderlik ve psikolojik güvenlik arasındaki iliş̧iye dair aşağıdaki hipotez geliştirilmiştir.

H2: Kapsayıcı liderlik, psikolojik güvenliği anlamlı ve pozitif yönde etkiler. 


\subsection{Psikolojik Güivenlik ile İş Performansı Arasındaki İlişki}

İş bağlamında psikolojik güvenlik, çalışanların yaratıcılığını açığa çıkarma ve çalışanları öğrenmekte özgür hissettirme yeteneği nedeniyle değerli bir olgudur. Bu sonuçların iş görevleri için anlamı göz önüne alındığında, psikolojik güvenliğin performansa katkıda bulunduğu ifade edilebilir. Bu ilişkinin bir kanıtı, örgütsel öğrenme üzerine yapılan çalışmada açıkça görülmektedir. Geri bildirim arama, yardım isteme ve hataları tartışma gibi uyarlanabilir davranışlar çalışanların performansı üzerinde önemli bir etkiye sahiptir çünkü bu durum çalışanların örgüte daha iyi uyum sağlamasına ve kendini geliştirmesine imkan sağlamaktadır. $\mathrm{Bu}$ davranışların potansiyel faydaları ödüllendirici olsa da, genellikle kişinin zayıflıklarını ortaya çıkarmaktadır (Edmondson, 1999:356). Örneğin, hataları kabul etmenin veya yardım istemenin bir sonucu olarak, bir kişi yetersiz görünebilir ve bu nedenle kişinin imajına olumsuz etki edebilir (Lee, 1997:357). Yüksek düzeyde psikolojik güvenlik algılayan çalışanların deney yapma, keşfetme ve öğrenme olasılı̆̆ daha yüksektir. Bu davranışlar, nihayetinde işin kalitesini veya verimliliğini artırarak çalışanların daha iyi performans elde etmelerine yardımc1 olabilecektir (Li ve Tan, 2013:407).

Yüksek düzeyde psikolojik güvenlik algılayan çalışanların daha iyi iş performansı ortaya koyabildiklerini destekleyen araştırma sonuçlarından hareketle aşağıdaki hipotez geliştirilmiştir.

H3: Psikolojik güvenlik, çalışanların iş performansını anlamlı ve pozitif yönde etkiler.

\subsection{Kapsayııı Liderlik ile İş Performansı Arasındaki İlişkide Psikolojik Güvenliğin Aracı Etkisi}

Carmeli ve diğ. (2014), dönüşümcü liderlik ve yaratıcı problem çözme arasındaki ilişkide psikolojik güvenlik ve düşünümselliğin aracılık rolünü araştırdıkları çalışma bulgularında, psikolojik güvenliğin hem doğrudan hem de dolaylı olarak düşünümsellik yoluyla, çalışanların yaratıcı problem çözme kapasitesi ile ilişkili olduğunu tespit etmişlerdir. Ayrıca araştırmacılar, dönüşümcü liderliğin psikolojik güvenlik ve düşünümsellik algıları aracılığıyla yaratıcı problem çözme kapasitesi ile ilişkili olduğunu ortaya koymuşlardır (Carmeli ve diğ., 2014:115). Gu ve diğ. (2013), Ar-Ge ekiplerinde sosyal sermaye ve inovasyon arasındaki ilişkide psikolojik güvenlik ve hatalardan öğrenme algısının aracı rollerini incelemişlerdir. Araştırmacılar, psikolojik güvenlik ve hatalardan öğrenme algısının, Ar-Ge ekiplerinde yapısal ve bilişsel sermaye ile yenilik arasındaki ilişkiye kısmen aracılık ettiğini ve Ar-Ge ekiplerinde ilişkisel sermaye ve yenilik arasındaki ilişkiye ise tam olarak aracılık ettiğini tespit etmişlerdir (Gu ve diğ., 2013:89). Taştan ve İşiaçık (2020), yenilikçi iş davranışı ile kurumsal sosyal sorumluluk arasındaki ilişkide psikolojik güvenliğin aracılık rolünü araştırdıkları çalışmalarında psikolojik güvenliğin aracılık etkisi olduğunu belirlemişlerdir. Ayrıca yenilikçi iş davranışı ile kurumsal sosyal sorumluluk arasında pozitif bir ilişki tespit etmişlerdir (Taştan ve İşiaçık, 2020:84).

Yukarıda bahsedilen bütün bu ilişkiler çerçevesinde kapsayıcı liderlik ile iş performansı arasındaki ilişkide psikolojik güvenliğin aracılık bir etkisi olabileceği kanaatine varılmış olup aşağıdaki hipotez geliştirilmiştir.

H4: Kapsayıcı liderlik ile iş performansı arasındaki ilişkide psikolojik güvenlik aracı rol oynar.

\section{YÖNTEM}

\subsection{Birinci Örneklem ve Amaç}

$\mathrm{Bu}$ çalışmanın yapılmasının amaçlarından biri; Carmeli ve dĭg. (2010) tarafından geliştirilmiş olan Kapsayıcı Liderlik Ölçeğinin Türkçe uyarlamasını yapmak ve Türkçe alanyazında kullanılıp kullanılamayacağını belirlemektir. Bu amaç kapsamında birinci örneklemde ölçeğin Türkçe uyarlamasını yapmak üzere sağlık çalışanlarından oluşan 136 anket kullanılmıştır. Anketlerde yer alan soruların samimi, tarafsız ve doğru bir şekilde doldurulması için katılımcılara anketin kapsamı, içeriği ve soruları ile ilgili gerekli bilgiler verilmiştir. Anketteki soruların sağlıklı bir şekilde cevaplanabilmesini sağlamak için kişilerle birebir irtibat halinde kalınmış olup, tamamen gönüllülük ilkesi esas alınmıştır. Elde edilen verilerde; araştırmaya katılan kadın çalışanların erkek çalışanlardan fazla olduğu (\%61), katılımcıların büyük çoğunluğunun 26-31 yaş aralığında olduğu $(\% 49,3)$, bekar çalışanlar ile evlilerin aynı olduğu (\%50), kıdeme göre büyük çoğunluğunun 4 yıl ve altı süreyle çalıştıkları $(\% 54,4)$ ve mesleklerine göre büyük çoğunluğunun doktor olduğu görülmüş̧ür $(\% 36,8)$.

\section{2. İkinci Örneklem ve Amaç}

$\mathrm{Bu}$ çalışmanın yapılmasının diğer bir amacı ise; kapsayıcı liderliğin çalışanların iş performansı üzerindeki etkisinde psikolojik güvenliğin aracılık etkisini belirlemektir. Araştırmanın evrenini bir devlet üniversitesindeki 1048 akademik personel oluşturmaktadır. Bu çalışma evreninden \%95 güven aralığında ve $\% 5$ hata payı ile seçilebilecek örneklem büyüklüğü 281 olarak belirlenmiştir (https://www.surveysystem.com/sscalc.htm). Anketlere geri dönüş yapma oranının düşük olabileceği ve 
verilerde yaşanabilecek kayıpların olasılı̆̆ı göz önüne alınarak 450 kişiye anket bizzat araştırmacı tarafindan ulaştırılmıştır. 450 kişiye ulaştırılan ankete 372 kişi geri dönüş sağlamıştır. Bunlardan 22 tanesi eksik veri girişleri yapıldığından dolayı değerlendirmeye tabi tutulmamıştır. Sonuç olarak 350 anket değerlendirilebilir nitelikte bulunarak analize dahil edilmiştir. Elde edilen verilerde; araştırmaya katılan erkek bireylerin kadın bireylerden fazla olduğu $(\% 67,1)$, katılımcıların büyük çoğunluğunun 38 ve üzeri yaşta olduğu $(\% 39,7)$, evli çalışanların bekar çalışanlardan fazla olduğu $(\% 76,6)$, kıdeme göre büyük çoğunluğunun 10-14 yıl süreyle mevcut kurumda çalıştıkları $(\% 29,1)$ ve unvanlarına göre katılımcıların büyük çoğunluğunun Dr. Öğr. Üyesi olduğu görülmüştür (\%32).

\subsection{Araştırmada Kullanılan Veri Toplama Araçları}

Araştırmanın nicel bir çalışma olmasından dolayı her iki örneklemde de veriler anket tekniği kullanılarak toplanmıştır. Çalışmanın belirlenen amaçlara ulaşmasını sağlamak amacıyla kapsayıcı liderlik, iş performansı ve psikolojik güvenlik kavramları hakkında hem yerli hem de yabancı literatür taranmış ve ölçüm araçları tespit edilmiştir.

\subsubsection{Kapsayıcı Liderlik Ölçeği}

Kapsayıcı liderlik davranışını ölçmek için Carmeli ve diğ. (2010) tarafından geliştirilen Kapsayıcı Liderlik Ölçeği kullanılmıştır. Açıklık, hazır bulunuşluk ve erişilebilirlik olarak 3 alt boyuttan oluşan bu ölçekte toplam 9 madde bulunmaktadır. Türkçe uyarlaması bulunmayan ölçeğin güvenilirlik ve geçerlilik analizleri bizzat yapılmıştır. Yapılan analizler sonucunda ölçeğin güvenilir ve geçerli olduğu tespit edilmiştir. Ölçeğin Cronbach Alfa değeri 0,944 olarak bulunmuştur. Ölçeği geliştiren araştırmacılar tarafindan ise Cronbach Alfa değeri 0,94 olarak bulunmuştur. Ölçek 5'li Likert tipindedir (1-Kesinlikle Katılmıorum, 2-Katılmıyorum, 3Kararsızım, 4-Katıliyorum ve 5-Kesinlikle Katıliyorum).

\subsection{2. İş Performansı Ölçeği}

Çalışanların iş performansı düzeylerini ölçmek için Kirkman ve Rosen (1999) ve Sigler ve Pearson (2000) tarafından geliştirilen İş Performansı Ölçeği kullanılmıştır. Ölçek 4 madde ve tek boyuttan oluşmaktadır. Ölçeğin Türkçe uyarlamasının çalışmalarda çok fazla kullanılmasından dolayı bu ölçek tercih edilmiştir. Ölçeğin Türkçe' ye uyarlaması Çöl (2008) tarafından yapılmıştır. Yapılan analizler neticesinde ölçeğin güvenilir ve geçerli olduğu tespit edilmiştir. Türkçe literatürde ölçeğin Cronbach Alfa değeri 0,827 olarak bulunmuştur. Ölçek 5'li Likert tipindedir (1-Kesinlikle Katılmıyorum, 2-Katılmıyorum, 3-Kararsızım, 4Kat1liyorum ve 5-Kesinlikle Katıliyorum).

\subsubsection{Psikolojik Güvenlik Ölçeği}

Kişilerin psikolojik güvenlik algılarını ölçmeye yönelik olarak Edmondson (1999) tarafından geliştirilen Psikolojik Güvenlik Ölçeği kullanılmıştır. Bu ölçek hem yerli hem de yabancı çalışmalarda çok fazla kullanıldığından dolayı tercih edilmiştir. Ölçek 7 madde ve tek boyuttan oluşmaktadır. Ölçeğin Türkçe' ye uyarlaması Yener (2015) tarafından yapılmış olup ölçeğin Türkçe literatürde kullanılabileceği tespit edilmiştir. Türkçe alanyazında Yener (2015) tarafından uyarlaması yapılan ölçeğin Cronbach Alfa değeri 0,810 olarak bulunmuştur. Ölçeği geliştiren araştırmacı tarafından ise Cronbach Alfa değeri 0,82 olarak bulunmuştur. Ölçek 5'li Likert tipindedir (1-Kesinlikle Katılmıyorum, 2-Katılmıyorum, 3-Kararsızım, 4-Kat1lyorum ve 5Kesinlikle Katıliyorum).

\subsection{Kapsayıcı Liderlik Ölçeğinin Türkçeye Çevirisi}

Sosyal bilimler alanında ölçek uyarlama ile ilgili yapılan çalışmalar, araştırmacıların veri toplama aracı elde etmeleri amacıyla başvurdukları bir yoldur. Ölçek geliştirmeden ziyade ölçek uyarlaması yapmak daha düşük maliyetli ve daha kolay bir uygulamadır. Farklı dilde oluşturulmuş bir ölçeğin Türkçe' ye uyarlaması bazı adımlar izlenerek yapılmaktadır (Brislin ve diğ., 1973). Bu çalışmada uyarlaması yapılan Kapsayıcı Liderlik Ölçeği Carmeli ve diğ. (2010) tarafından geliştirilmiş olan 9 soruluk bir ölçektir. Araştırmac1 tarafından İngilizce dilinde oluşturulmuş bu ölçek, ilk olarak anadili Türkçe olan ve hem Türkçe' ye hem de İngilizce' ye hakim iki dilbilimci tarafından Türkçe' ye çevrilmiş̧ir. İkinci adımda yine iki dile de hakim ilk aşamadaki kişilerden farklı iki dilbilimci tarafından Türkçe' den İngilizce' ye çevrilmiştir. Üçüncü aşamada ise iki dile de hakim sosyal bilimler alanında uzman üç öğretim üyesine danışılımıştır. Uzman kişilerden alınan geribildirim sonucunda iki dile de hakim önceki aşamaların hiçbirinde görev alamamış bir dilbilimciye kapsayıcı liderlik ölçeğinin orijinal hali ve çevirisi incelettirilmiş ve sosyal bilimler alanında uzman ve 
İngilizce' ye hakim iki öğretim üyesine incelettirilip onaylatıldıktan sonra kapsayıcı liderlik ölçeğinin Türkçe' ye çevirisinin uygun olabileceği sonucuna ulaşılmıştır.

\section{5. İstatistiksel Analiz}

Çalışmada elde edilen verilerin analizi için SPSS 25 ve AMOS 24 paket programları kullanılmıştır. Veriler iki farklı örneklemden yararlanılarak ve iki aşamada analiz edilmiştir. Birinci aşamada ilk örneklemden (136 sağlık çalışanı) elde edilen verilere, Carmeli ve diğ. (2010) tarafından geliştirilen 3 alt boyuttan oluşan toplam 9 maddeli Kapsayıcı Liderlik Ölçeğinin güvenirlilik ve geçerliliğini ortaya koymak amacıyla; güvenirlilik analizi, korelasyon analizi, maddelere ilişkin üst ve alt grup ortalamalarına dair bağımsız $t$ testi, keşfedici faktör analizi ve doğrulayıcı faktör analizleri yapılmıştır. İkinci aşamada ise diğer örneklemden (350 akademik personel) elde edilen veriler kullanılarak her bir ölçeğe ait güvenirlilik ve doğrulayıcı faktör analizleri yapılmıştır. Ardından araştırma hipotezlerini (H1, H2, H3 ve H4) test etmek amaciyla Andrew F. Hayes tarafından geliştirilen PROCESS Macro Model 4' den yararlanılmıştır (Hayes, 2017). Yapılan analizler neticesinde ortaya çıkan hipotez testi sonuçlanı istatistiksel olarak yorumlanmıştır.

\section{BULGULAR}

\subsection{Birinci Örnekleme Ait Bulgular}

\subsubsection{Kapsayıcı Liderlik Ölçeğine Ait Güvenirlilik Analizi}

Kapsayıcı liderlik ölçeğinin güvenirlilik analizi için ölçeğin içsel tutarlılığını gösteren Cronbach Alfa katsayısı hesaplanarak incelenmiştir. Kapsayıcı Liderlik Ölçeğinin güvenirliliğini belirlemek amacıyla yapılan analizler neticesinde ortaya çıkan bulgular Tablo 1'de özetlenmiştir.

Tablo 1. Kapsayıcı Liderlik Ölçeğine Ait Güvenirlilik Analizi Sonuçları

\begin{tabular}{|c|c|c|c|c|c|c|}
\hline Madde No & $\begin{array}{c}\text { Aritmetik } \\
\text { Ortalama }\end{array}$ & $\begin{array}{c}\text { Standart } \\
\text { Sapma }\end{array}$ & $\begin{array}{c}\text { Madde Silinirse } \\
\text { Ölçeğin } \\
\text { Ortalaması }\end{array}$ & $\begin{array}{c}\text { Madde Silinirse } \\
\text { Ölçeğin } \\
\text { Varyansı }\end{array}$ & $\begin{array}{c}\text { Düzeltilmiş } \\
\text { Madde Toplam } \\
\text { Puan } \\
\text { Korelasyonu }\end{array}$ & $\begin{array}{c}\text { Madde Silinirse } \\
\text { Ölçeğin } \\
\text { Cronbach Alfa } \\
\text { Katsayısı }\end{array}$ \\
\hline A1 & 3,0000 & 1,13529 & 25,7426 & 52,430 &, 793 &, 937 \\
\hline A2 & 2,9485 & 1,10433 & 25,7941 & 51,942 &, 854 &, 933 \\
\hline A3 & 3,0294 & 1,13491 & 25,7132 & 52,058 &, 819 &, 935 \\
\hline HB1 & 3,1250 & 1,14463 & 25,6176 & 52,164 &, 803 &, 936 \\
\hline HB2 & 3,3897 &, 97504 & 25,3529 & 57,356 &, 572 &, 948 \\
\hline HB3 & 3,4853 & 1,04694 & 25,2574 & 53,289 &, 809 &, 936 \\
\hline HB4 & 3,3309 & 1,05448 & 25,4118 & 53,888 &, 759 &, 939 \\
\hline E1 & 3,1176 & 1,12913 & 25,6250 & 51,836 &, 839 &, 934 \\
\hline E2 & 3,3162 & 1,09343 & 25,4265 & 53,061 &, 785 &, 937 \\
\hline GENEL & $\begin{array}{c}\text { Aritmetik } \\
\text { Ortalama }\end{array}$ & $\begin{array}{c}\text { Standart } \\
\text { Sapma } \\
28,7426\end{array}$ & & Varyans & & Cronbach Alfa \\
\hline
\end{tabular}

Not: $A=$ Açıklık; $\mathrm{HB}=$ Hazır bulunuşluk; $\mathrm{E}=$ Erişilebilirlik

Tablo 1' deki değerler incelendiğinde ölçekte yer alan bütün maddelerin toplam puan korelasyonunun ,40' dan yüksek olduğu görülmektedir. Ayrica bulgular, bu maddelerden herhangi birinin ölçekten silinmesi durumunda Cronbach Alfa katsayısı değerinde önemli seviyede bir değişiklik olmayacağını göstermektedir. Bu sebeplerden dolayı ölçekten herhangi bir maddenin çıkarılmasına ihtiyaç duyulmamıştır. Ölçeğin Cronbach Alfa değerinin ,944 olarak çıkması güvenirliliğinin yüksek olduğunu göstermektedir.

Ölçekte yer alan maddelerin birbirleriyle olan ilişkilerinin belirlemesi kapsamında maddeler arası korelasyon değerleri de analiz edilmiştir. Bir madde üstündeki puanların ölçekte yer alan diğer bütün maddelere ait puanlar ile ne derece ilişkili olduğu, maddeler arası korelasyon değerleri ile incelenmektedir. Yapılan analizler neticesinde ortaya çıkan bulgular Tablo 2'de özetlenmiştir.

Tablo 2. Maddeler Arası Korelasyon Değerleri

\begin{tabular}{|c|c|c|c|c|c|c|c|c|c|}
\hline Değișkenler & $\mathbf{1}$ & $\mathbf{2}$ & $\mathbf{3}$ & $\mathbf{4}$ & $\mathbf{5}$ & $\mathbf{6}$ & $\mathbf{7}$ & $\mathbf{8}$ & $\mathbf{9}$ \\
\hline $\mathrm{A} 1$ & 1 & & & & & & & & \\
\hline $\mathrm{A} 2$ &, $839^{* *}$ & 1 & & & & & & & \\
\hline $\mathrm{A} 3$ &, $719^{* *}$ &, $805^{* *}$ & 1 & & & & & & \\
\hline
\end{tabular}




\begin{tabular}{|c|c|c|c|c|c|c|c|c|c|}
\hline HB1 &, $713^{* *}$ &, $802^{* *}$ &, $761^{* *}$ & 1 & & & & \\
\hline HB2 &, $475^{* *}$ &, $521^{* *}$ &, $451^{* *}$ &, $480^{* *}$ & 1 & & & & \\
\hline HB3 &, $636^{* *}$ &, $675^{* *}$ &, $667^{* *}$ &, $654^{* *}$ &, $488^{* *}$ & 1 & & & \\
\hline HB4 &, $644^{* *}$ &, $651^{* *}$ &, $673^{* *}$ &, $598^{* *}$ &, $472^{* *}$ &, $706^{* *}$ & 1 & & \\
\hline E1 &, $653^{* *}$ &, $706^{* *}$ &, $679^{* *}$ &, $688^{* *}$ &, $503^{* *}$ &, $778^{* *}$ &, $707^{* *}$ & 1 & \\
\hline E2 &, $585^{* *}$ &, $615^{* *}$ &, $655^{* *}$ &, $625^{* *}$ &, $530^{* *}$ &, $764^{* *}$ &, $622^{* *}$ &, $834^{* *}$ & 1 \\
\hline
\end{tabular}

Not: **p $<0,01 ; \mathrm{A}=$ Açıklık; $\mathrm{HB}=$ Hazır bulunuşluk; $\mathrm{E}=$ Erişilebilirlik

Tablo 2' deki değerler incelendiğinde ,451 ile ,839 aralığında maddeler arası korelasyon değerlerinin olduğu görülmektedir. Bulgulara göre, maddelerin birbirleriyle pozitif yönde bir ilişki içerisinde olduğu söylenebilir.

Güvenirlilik ve korelasyon analizlerinden sonra faktör bazlı ayırt etme aşamasına geçilmiştir. Ölçeğe ait $\% 27$ ' lik üst ve alt grupların skorları arasında anlamlı düzeyde bir farklılı̆̆ın olup olmadığını tespit etmek amacıyla bağımsız t-testi uygulanmıștır. Bu analizin yapılma amacı, her maddeye ait verilmiş olan yanıtın üst ve alt gruplar arasında farklılı̆̆ın olup olmadığını yani ayıt edebilme gücünü belirlemektir. Yapılan analizler neticesinde ortaya çıkan bulgular Tablo 3'de özetlenmiştir.

Tablo 3. Maddelere İlişkin Üst ve Alt Grup Ortalamalarına Dair Bağımsız t Testi Sonuçları

\begin{tabular}{|c|c|c|c|c|c|}
\hline Madde No & Grup & Ort. & Std. Sapma & t & p \\
\hline \multirow{2}{*}{ KL1 } & Üst grup & 4,0833 &, 50000 & 14,705 &, 000 \\
\cline { 2 - 6 } & Alt grup & 1,7778 &, 79682 & 14,705 &, 000 \\
\hline \multirow{2}{*}{ KL2 } & Üst grup & 4,0833 &, 50000 & 17,863 &, 000 \\
\cline { 2 - 6 } & Alt grup & 1,7500 &, 60356 & 17,863 &, 000 \\
\hline \multirow{2}{*}{ KL3 } & Üst grup & 4,1944 &, 40139 & 19,216 &, 000 \\
\cline { 2 - 6 } & Alt grup & 1,7500 &, 64918 & 19,216 &, 000 \\
\hline \multirow{2}{*}{ KL4 } & Üst grup & 4,2500 &, 50000 & 18,599 &, 000 \\
\cline { 2 - 6 } & Alt grup & 1,8889 &, 57459 & 18,599 &, 000 \\
\hline \multirow{2}{*}{ KL5 } & Üst grup & 4,2222 &, 54043 & 10,941 &, 000 \\
\cline { 2 - 6 } & Alt grup & 2,5000 &, 77460 & 10,941 &, 000 \\
\hline \multirow{2}{*}{ KL6 } & Üst grup & 4,3333 &, 53452 & 12,294 &, 000 \\
\cline { 2 - 6 } & Alt grup & 2,2778 &, 84890 & 12,294 &, 000 \\
\hline \multirow{2}{*}{ KL7 } & Üst grup & 4,2778 &, 51331 & 12,617 &, 000 \\
\cline { 2 - 6 } & Alt grup & 2,2222 &, 83190 & 12,617 &, 000 \\
\hline \multirow{2}{*}{ KL8 } & Üst grup & 4,2500 &, 60356 & 16,302 &, 000 \\
\cline { 2 - 6 } & Alt grup & 1,8611 &, 63932 & 16,302 &, 000 \\
\hline \multirow{2}{*}{ KL9 } & Üst grup & 4,306 &, 4672 & 11,957 &, 000 \\
\cline { 2 - 6 } & Alt grup & 2,194 &, 9508 & 11,957 &, 000 \\
\hline
\end{tabular}

Not: N: 136; KL= Kapsayıc liderlik

Tablo 3 incelendiğinde, tüm gruplar için ortaya çıkan farkl11ıkların anlamlı olduğu görülmektedir $(\mathrm{p}<, 001)$. Elde edilen verilere göre, ölçekte yer alan maddelerin birbirlerinden bağımsız oldukları sonucuna ulaşılmıştır.

\subsubsection{Kapsayıcı Liderlik Ölçeğine Ait Keşfedici Faktör Analizi}

Kapsayıcı Liderlik Ölçeğinin güvenirlilik analizinin yapılmasının ardından geçerliliğini belirlemek amacıyla keşfedici faktör analizi (KFA) uygulanmıştır. Yapılan analizler neticesinde ortaya çıkan veriler Tablo 4' de verilmiştir.

Tablo 4. Keşfedici Faktör Analizi Sonuçları

\begin{tabular}{|c|c|c|c|c|c|}
\hline Madde No & $\begin{array}{l}\text { Faktör } \\
\text { Yükleri }\end{array}$ & Özdeğer & $\begin{array}{c}\text { Açıklanan } \\
\text { Varyans (\%) }\end{array}$ & $\begin{array}{c}\text { Toplam } \\
\text { Varyans }(\%)\end{array}$ & $\begin{array}{l}\text { Cronbach } \\
\text { Alfa }\end{array}$ \\
\hline KL1. Yöneticim, yeni fikirlere açıktır. & ,841 & \multirow{4}{*}{6,234} & \multirow{4}{*}{69,271} & \multirow{4}{*}{69,271} & \multirow{4}{*}{,944 } \\
\hline $\begin{array}{l}\text { KL2. Yöneticim, iş süreçlerini } \\
\text { iyileştirebilecek yeni firsatlara önem verir. }\end{array}$ & ,889 & & & & \\
\hline $\begin{array}{l}\text { KL3. Yöneticim, istenen hedefleri ve bu } \\
\text { hedeflere ulaşma yollarını tartışmaya açıktır. }\end{array}$ & 863 & & & & \\
\hline $\begin{array}{l}\text { KL4. Yöneticim, sorunlar hakkında istişare } \\
\text { yapmaya hazırdır. }\end{array}$ & ,850 & & & & \\
\hline
\end{tabular}




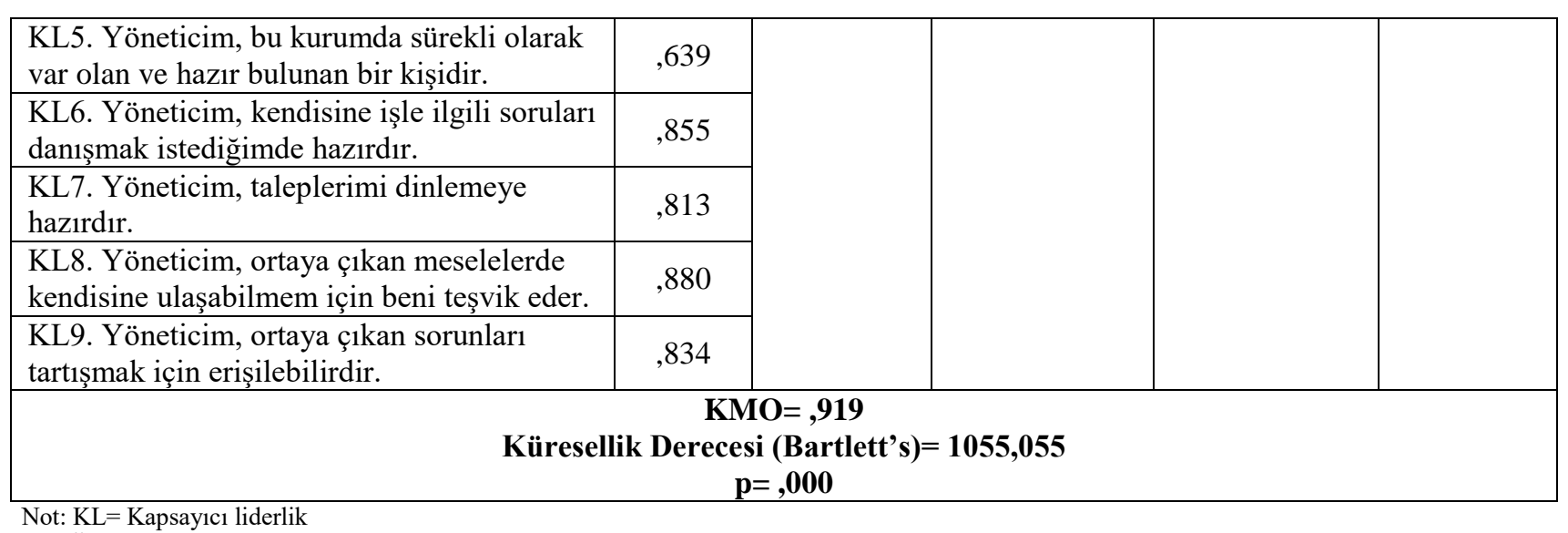

Ölçeğin faktör analizine uygun olup olmadığını yorumlayabilmek için Kaiser-Meyer-Olkin (KMO) ve Bartlett's Küresellik testi sonuçlarının ele alınması gerekmektedir. Tablo 4 incelendiğinde KMO değerinin ,919 olarak çıkması $(\mathrm{KMO}>, 60)$ faktör analizi için örneklemin yeterli büyüklükte olduğunu göstermektedir. Yine tablodan hareketle Bartlett's Küresellik testinin $(1055,055 ; p=, 000)$ anlamlı olması $(p \leq 0,05)$ ise verilerin faktör analizine uygun olduğunu göstermektedir. Ayrıca tablodaki sonuçlar incelendiğinde ölçekteki her bir maddenin faktör yüklerinin 0,40 ' dan yüksek olduğu görülmektedir. Ölçekte yer alan her bir maddenin faktör yüklerinin ,639 ile ,889 arasında değiştiği görülmektedir. Yani bu sonuç, maddelerin faktörü nitelediğini ortaya koymaktadır. Analiz sonucuna göre, ölçekte bulunan toplam 9 maddenin özdeğeri 1' den yüksek olan tek bir maddede birleştiği görülmektedir. Bu maddeler toplam varyansın \%69,271' ini açıklamaktadır.

Yukarıda bahsedilen tüm analizler neticesinde, Carmeli ve diğ. (2010) tarafından geliştirilen açıklık, hazır bulunuşluk ve erişilebilirlik olarak 3 alt boyuttan oluşan toplam 9 maddeli kapsayıcı liderlik ölçeğinin Türkçe' ye uyarlanmasında yapılan keşfedici faktör analizi sonuçları incelendiğinde ölçeğin Türkçe alanyazında tek boyutlu olarak ele alınması gerektiği kanaatine varılmıştır. Açıklık alt boyutundaki sorulardan biri olan "Yöneticim, istenen hedefleri ve bu hedeflere ulaşma yollarını tartışmaya açıktır", hazır bulunuşluk alt boyutundaki sorulardan biri olan "Yöneticim, kendisine işle ilgili soruları danışmak istediğimde hazırdır" ve erişilebilirlik alt boyutundaki sorulardan biri olan "Yöneticim, ortaya çıkan sorunları tartışmak için erişilebilirdir" soruları Türkçe literatüründe ve kültüründe birbirleriyle aynı veya benzer nitelikte olan sorulardır. Yani katılımcıların kapsayıcı liderlik ölçeğindeki her bir soruyu aynı fikir ve düşünceye sahip olarak yanıtladıkları tespit edilmiştir. Katılımcıların her bir soruyu aynı mantık, his ve düşünce kapsamında değerlendirdikleri görülmüştür. Sonuç olarak, dil ve kültür farkl1lıklarından dolayı ölçeğin orijinal halinde 3 alt boyut olmasına karşın, yapılan analizler neticesinde ölçeğin Türkçe' ye uyarlanması neticesinde literatürde tek boyutta ele alınması gerektiğinin faydalı olacağı önerilmektedir.

\subsubsection{Kapsayıcı Liderlik Ölçeğine Ait Doğrulayıcı Faktör Analizi}

Kapsayıcı liderlik ölçeğinde yer alan maddelerin keşfedici faktör analizi sonucunda oluşan faktör yapısının uyumunu belirlemek amacıyla doğrulayıcı faktör analizi (DFA) yapılmıştır. Ölçeğe ait uyum iyiliği değerleri incelendiğinde KL1-KL2, KL6-KL8, KL8-KL9 ve KL6-KL9 maddeleri arasında modifikasyonlar yapılmıştır. Modifikasyon işleminin ardından elde edilen değerler Şekil 1' de verilmiştir. 


\section{Şekil 1. Kapsayıcı Liderlik Ölçeğine Ait Doğrulayıcı Faktör Analizi}

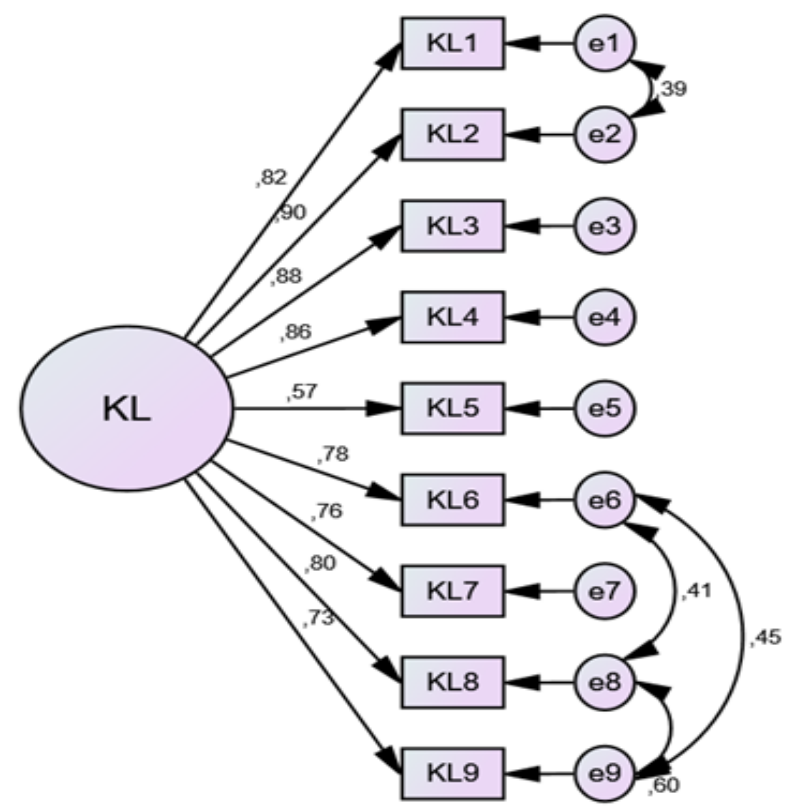

Şekil 1 incelendiğinde ölçekte yer alan maddelerin standardize edilmiş faktör yüklerinden her birinin $0,5^{\prime}$

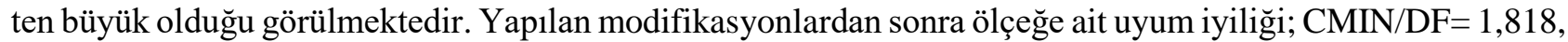
$\mathrm{NFI}=0,961, \mathrm{CFI}=0,982, \mathrm{IFI}=0,982$ ve $\mathrm{TLI}=0,972$ değerlerinin iyi uyum aralığında, $\mathrm{RMSEA}=0,078, \mathrm{GFI}=$ 0,937 ve AGFI $=0,877$ değerlerinin ise kabul edilebilir uyum aralığında oldukları tespit edilmiştir. Kapsayıcı liderlik ölçeğine ait doğrulayıcı faktör analiz sonuçları ele alındığında ölçeğin tek faktörlü yapıya uyum gösterdiği belirlenmiştir.

\section{2. İkinci Örnekleme Ait Bulgular}

\subsection{1. Ölçeklere Ait Güvenirlik Analizleri}

9 madde ve tek boyuttan oluşan kapsayıcı liderlik ölçeğinin güvenirlilik analizi için ölçeğin içsel tutarlılığını gösteren Cronbach Alfa katsayısı hesaplanarak incelenmiştir. Yapılan analiz sonucunda ölçeğin Cronbach Alfa değeri ,947 olarak bulunmuştur. Bu sonuç ölçeğin güvenirliliğinin yüksek olduğunu göstermektedir.

4 madde ve tek boyuttan oluşan iş performansı ölçeğinin içsel tutarlılığını ölçmek amacıyla yapılan analiz neticesinde Cronbach Alfa değeri ,891 olarak tespit edilmiştir. Bu sonuç ölçeğin güvenirliliğinin yüksek olduğunu göstermektedir.

7 madde ve tek boyuttan oluşan psikolojik güvenlik ölçeğinin güvenirlilik analizi için ölçeğin içsel tutarlılığını gösteren Cronbach Alfa değeri ,902 olarak bulunmuştur. Bu sonuç ölçeğin güvenirliliğinin yüksek olduğunu göstermektedir.

Araştırmamızdaki kapsayıcı liderlik, iş performansı ve psikolojik güvenlik ölçekleri arasındaki ilişkinin büyüklüğünü ve yönünü belirlemek amacıyla korelasyon analizi yapılmıştır. Her bir değişkene ait ortalama ve standart sapma değerleri ile değişkenlerin birbirleriyle olan ilişkilerini gösteren korelasyon katsayıları Tablo 5' de verilmiștir.

Tablo 5. Değişkenler Arasındaki İlişki

\begin{tabular}{|c|c|c|c|c|c|}
\hline Faktörler & Ort. & Std. Sapma & $\begin{array}{c}\text { Kapsayıcı } \\
\text { Liderlik }\end{array}$ & İş Performansı & $\begin{array}{c}\text { Psikolojik } \\
\text { Güvenlik }\end{array}$ \\
\hline Kapsayıcı Liderlik & 3,867 & 815 & 1 & & \\
\hline İş Performansı & 3,720 & ,720 & $\begin{array}{c}, 391 * * \\
(\mathrm{p}=0,000)\end{array}$ & 1 & \\
\hline Psikolojik Güvenlik & 3,615 & ,797 & $\begin{array}{c}, 701 * * \\
(\mathrm{p}=0,000)\end{array}$ & $\begin{array}{c}398 * * \\
(\mathrm{p}=0,000)\end{array}$ & 1 \\
\hline
\end{tabular}

Not: $* * \mathrm{p}<0,01$ 
Tablo 5' e bakıldığında; bağımsız değişken kapsayıcı liderlik ile bağımlı değişken iş performansı arasında \%99 önem düzeyinde pozitif yönlü orta seviyede anlamlı bir ilişki bulunmaktadır $(r=0,391 ; p=0,000) . \mathrm{Bu}$ durum yöneticilerin çalışanlara karşı kapsayıcı davranış tutumu içerisinde olduklarında, çalışanların iş performanslarının olumlu yönde artacağ 1 şeklinde yorumlanabilir.

Bağımlı değişken kapsayıcı liderlik ile aracı değişken psikolojik güvenlik arasında \%99 önem düzeyinde pozitif yönlü yüksek derecede anlamlı bir ilişki bulunmaktadır $(\mathrm{r}=0,701 ; \mathrm{p}=0,000)$. Bu sonuç liderin kapsayıcılığı arttıkça veya azaldıkça çalışanların örgüt içerisinde algıladıkları psikolojik güvenlik düzeylerinin de artacağı veya azalacağı biçiminde yorumlanabilir.

Psikolojik güvenlik ile iş performansı arasında ise pozitif yönlü orta düzeyde anlamlı bir ilişki bulunmaktadır $(\mathrm{r}=0,398 ; \mathrm{p}=0,000)$. Bu durum kurumda psikolojik güvenlik algısı arttıkça çalışanların iş performanslarının da artacağı şeklinde ifade edilebilir.

\subsection{2. Öıçeklere Ait Doğrulayııı Faktör Analizleri}

Çalışma kapsamında birinci örneklemden elde edilen tek faktörlü kapsayıcı liderlik ölçeğinde yer alan maddelerin faktör yapısına uyumunu belirlemek amaciyla ikinci örneklemden elde edilen verilerle AMOS 22 programı kullanılarak doğrulayıcı faktör analizi yapılmıştır. Yapılan analiz neticesinde ortaya çıkan; $\mathrm{CMIN} / \mathrm{DF}=2,948, \mathrm{NFI}=0,976, \mathrm{CFI}=0,984, \mathrm{GFI}=0,958, \mathrm{AGFI}=0,919, \mathrm{IFI}=0,984$ ve $\mathrm{TLI}=0,975$ değerlerinin iyi uyum aralığında, RMSEA=0,075 değerinin ise kabul edilebilir uyum aralığında olduğu görülmüştür.

Çalışanların iş performans düzeylerini ölçmek amacıyla kullanılan iş performansı ölçeğinin tek faktörlü yapısıyla uyumunu belirlemek amacıyla doğrulayıcı faktör analizi yapılmıştır. Yapılan analiz sonucunda; $\mathrm{CMIN} / \mathrm{DF}=1,491, \mathrm{RMSEA}=0,037, \mathrm{NFI}=0,998, \mathrm{CFI}=0,999, \mathrm{GFI}=0,998, \mathrm{AGFI}=0,979, \mathrm{IFI}=0,999$ ve TLI= 0,997 değerlerinin iyi uyum aralığında oldukları görülmüştür. İş performansı ölçeğine ait doğrulayıcı faktör analiz sonuçları ele alındığında ölçeğin tek faktörlü yapıya uyum gösterdiği tespit edilmiştir.

Son olarak tek boyutlu psikolojik güvenlik ölçeğinde yer alan maddelerin faktör yapısına uyumunu belirlemek amacıyla doğrulayıcı faktör analizi yapılmıştır. Analiz sonucunda; CMIN/DF= 2,901, NFI= 0,975, $\mathrm{CFI}=0,983, \mathrm{GFI}=0,973, \mathrm{AGFI}=0,938, \mathrm{IFI}=0,983$ ve $\mathrm{TLI}=0,971$ değerlerinin iyi uyum aralığında, $\mathrm{RMSEA}=$ 0,074 değerinin ise kabul edilebilir uyum aralığında olduğu tespit edilmiştir.

\subsection{Hipotezlerin Test Edilmesi}

Araştırma hipotezlerini test etmek amacıyla Andrew F. Hayes tarafından geliştirilen PROCESS Macro Model 4' den yararlanılmıştır. Yapılan analizler neticesinde ortaya çıkan hipotez testi sonuçları Tablo 6' da gösterilmiştir.

Tablo 6. Aracı Etkiye İlişkin Regresyon Analiz Sonuçları

\begin{tabular}{|c|c|c|c|c|c|c|}
\hline \multirow{2}{*}{\multicolumn{3}{|c|}{$\begin{array}{l}\text { KL' nin PG aracılığıyla İP üzerindeki doğrudan } \\
\text { etkisi }\end{array}$}} & $\mathbf{B}$ & Std. Hata & $\mathbf{t}$ & $\mathbf{p}$ \\
\hline & & & 0,3921 & 0,0588 & 6,6718 & 0,030 \\
\hline \multicolumn{3}{|c|}{ KL' nin PG üzerindeki etkisi } & 0,7433 & 0,0340 & 21,8381 & 0,000 \\
\hline \multicolumn{3}{|c|}{ PG' nin İP üzerindeki etkisi } & 0,4690 & 0,0410 & 11,330 & 0,000 \\
\hline \multicolumn{3}{|c|}{ KL' nin İP üzerindeki toplam etkisi } & 0,5142 & 0,0385 & 13,3471 & 0,000 \\
\hline & Etki & Std. Hata & ED 95\% GA & EY 95\% GA & $\mathbf{Z}$ & $\mathbf{p}$ \\
\hline \multirow[t]{2}{*}{$\begin{array}{l}\text { Dolaylı etki ve Sobel } \\
\text { testi }\end{array}$} & 0,1221 & 0,0451 & 0,0460 & 0,2825 & 2,70 & 0,006 \\
\hline & Etki & Std. Hata & ED 99\% GA & EY 99\% GA & & \\
\hline $\begin{array}{l}\text { Bootstrap Edilmiş } \\
\text { Dolaylı Etki }\end{array}$ & 0,1221 & 0,0465 & 0,0326 & 0,2163 & & \\
\hline
\end{tabular}

Not: N=350; EDGA=En Düşük Güven Aralığı; EYGA= En Yüksek Güven Aralığı; KL= Kapsayıcı liderlik; PG=Psikolojik güvenlik; IP= İş performansı

Tablo 6 incelendiğinde; kapsayıcı liderliğin iş performansı üzerindeki etkisinin pozitif yönlü ve anlamlı olduğu $(\beta=0,5142 ; \mathrm{t}=13,3471 ; \mathrm{p}=0,000)$ görülmektedir. Bu sonuca göre, "Kapsayıcı liderlik, çalışanların iş performansinı anlamlı ve pozitif yönde etkiler" yönündeki Hipotez 1' in kabul edildiğini söyleyebiliriz.

Kapsayıcı liderliğin psikolojik güvenlik üzerindeki etkisine yönelik sonuçlar ele alındığında; bu iki değişken arasında pozitif yönlü ve anlamlı $(\beta=0,7433 ; \mathrm{t}=21,8381 ; \mathrm{p}=0,000)$ bir ilişki olduğu görülmektedir. Dolayısıyla, "Kapsayıcı liderlik, psikolojik güvenliği anlamlı ve pozitif yönde etkiler" yönündeki Hipotez 2'nin kabul edildiğini söyleyebiliriz. 
Yine tablodan hareketle psikolojik güvenliğin iş performansı üzerindeki etkisinin pozitif yönlü ve anlamlı olduğu $(\beta=0,4690 ; \mathrm{t}=11,330 ; \mathrm{p}=0,000)$ görülmektedir. Bu bulguya göre, "Psikolojik güvenlik, çallşanların iş performansını anlamlı ve pozitif yönde etkiler" yönündeki Hipotez 3' ün kabul edildiğini söyleyebiliriz.

Aracı etkinin anlamlı olup olmadığını belirlemek amacıyla Sobel testi yapılmıştır. Sobel testine göre dolaylı etkinin anlamlı olduğu tespit edilmiştir (Sobel $\mathrm{z}=2,70, \mathrm{p}=0,006$ ). Akabinde Bootstrap sonuçlarının $\% 99$ güven düzeyinde güven aralıklarının $(0,0326,0,2163)$ sıfir içermemesinin Sobel testi çıktılarını desteklediği sonucuna varılmıştır. Bu sonuçlar, psikolojik güvenliğin aracılık etkisinin istatistiki olarak anlamlılığını ortaya koymaktadır. Kapsayıcı liderlik ile iş performansı arasındaki ilişkide psikolojik güvenliğin aracılık etkisine dair sonuçlar ele alındığında; kapsayıcı liderliğin iş performansı üzerindeki toplam $(\beta=0,5142 ; t=13,3471 ; p=$ $0,000)$ ve dolaylı etkisinin $(\beta=0,1221 ; p=0,006)$ anlamlı olduğu görülmektedir. Kapsayıcı liderliğin iş performansı üzerindeki doğrudan etkisinin $(\beta=0,3921 ; \mathrm{t}=6,6718 ; \mathrm{p}=0,030)$ düştüğü fakat anlamlı olduğu görülmektedir. Bu sonuçlardan hareketle kapsayıcı liderliğin iş performansı üzerindeki etkisinde psikolojik güvenliğin kısmi aracılık etkisine sahip olduğunu söyleyebiliriz. Başka bir ifade ile kapsayıcı liderliğin iş performansı üzerindeki toplam etkisinde, psikolojik güvenlik aracılığıyla aktarılan hem dolaylı hem de doğrudan etkisinin anlamlı olduğu tespit edilmiştir. Bu sonuçlara dayanarak; "Kapsayıcı liderlik ile işs performansı arasındaki ilişside psikolojik güvenlik aracı rol oynar" yönündeki Hipotez 4' ün kabul edildiğini söyleyebiliriz.

\section{SONUÇ VE TARTIŞMA}

Bu çalışmada, Carmeli ve diğ. (2010) tarafından geliştirilmiş olan kapsayıcı liderlik ölçeğinin Türkçeye uyarlanması amaçlanmıştır. Ayrıca kapsayıcı liderliğin çalışanların iş performansı üzerindeki etkisinde psikolojik güvenliğin aracılık etkisi de belirlenmeye çalışılmıştır.

Araştırmada öncelikle kapsayıcı liderlik ölçeğinin Türkçeye uyarlanması kapsamında sağlık çalışanlarının oluşturduğu örneklemden veriler toplanmıştır. Brislin ve diğ. (1973) tarafından geliştirilen ölçek uyarlama adımları 1şığında, ölçeğin Türkçeye çevirisi gerçekleştirilmiştir. Elde edilen veriler kullanılarak kapsayıcı liderlik ölçeğinin hem güvenilirliğini hem de geçerliliğini belirlemek amacıyla birtakım analizler yapılmıştır. Yapılan analizler neticesinde 3 alt boyut ve 9 maddeden oluşan kapsayıcı liderlik ölçeğinin Türkçe alanyazında tek boyutlu olarak ele alınmasının faydalı olacağı sonucuna ulaşılmıştır. Dolayısıyla kapsayıcı liderlik ölçeğinin Türkiye' de yapılacak araştırmalar için uygun olabileceği belirlenmiştir.

Araştırmada kapsayıcı liderliğin çalışanların iş performansı üzerindeki etkisinde psikolojik güvenliğin aracılık etkisini belirlemek amacıyla akademik personellerin oluşturduğu örneklemden elde edilen veriler kullanılmıştır. Yapılan analizler sonucunda kapsayıcı liderlik ile iş performansı arasında pozitif yönlü anlamlı bir ilişki bulunmuştur. Elde edilen bu sonuç daha önce yapılan araştırmalarda (örneğin; Qi ve Liu, 2017; Xiang ve diğ., 2017; Yu, 2019) elde edilen sonuçlarla örtüşmektedir. Bu durum yöneticilerin çalışanlara karş1 kapsayıcı davranış tutumu içerisinde olduklarında, çalışanların iş performanslarının olumlu yönde artacağı şeklinde yorumlanabilir. Kapsayıcı liderliğin psikolojik güvenlik ile ilişkisi incelendiğinde, pozitif yönlü anlamlı bir ilişki olduğunu söylemek mümkündür. Elde edilen bu sonuç daha önce yapılan araştırmalarda (örneğin; Carmeli ve di ̆. ., 2010; Hirak ve diğ., 2012; Khan ve diğ., 2020) elde edilen sonuçlarla örtüşmektedir. Sonuçlara göre, liderin kapsayıcılığı arttıkça veya azaldıkça çalışanların örgüt içerisinde algıladıkları psikolojik güvenlik düzeylerinin de artacağı veya azalacağ 1 ifade edilebilir. Aracı değişken olan psikolojik güvenliğin iş performansı ile ilişkisi incelendiğinde, pozitif yönlü anlamlı bir ilişki bulunmuştur. Elde edilen bu sonuç daha önce yapılan araştırmalarda (örneğin; Bradley ve diğ., 2012; Chandrasekaran ve Mishra, 2012; Li ve Tan, 2013) elde edilen sonuçlarla örtüşmektedir. Bu durum kurumda psikolojik güvenlik algısı arttıkça çalışanların iş performanslarının da artacağı şeklinde ifade edilebilir.

Aracı etkiye ilişkin regresyon analiz sonuçlarına göre; kapsayıcı liderliğin iş performansı üzerindeki etkisinin pozitif yönlü ve anlamlı olduğu görülmüştür. Kapsayııı liderliğin psikolojik güvenlik üzerindeki etkisine yönelik bulgular ele alındığında; bu iki değişken arasında pozitif yönlü ve anlamlı bir ilişki olduğu sonucuna varılmıştır. Psikolojik güvenliğin iş performansı üzerindeki etkisine bakıldığında pozitif yönlü ve anlamlı bir ilişki tespit edilmiştir. Sobel testi sonuçlarına göre, psikolojik güvenliğin aracılık etkisinin istatistiki olarak anlamlı olduğu görülmüştür. Kapsayıcı liderlik ile iş performansı arasındaki ilişkide psikolojik güvenliğin aracılık etkisine dair sonuçlarda, kısmi bir aracılık etkinin olduğu belirlenmiştir.

Lider kapsayıcı davranışlar içerisinde olduğunda, örgütte çalışanlar arasında psikolojik güvenliğin gelişimi de kolaylaşacaktır. Çalışanlar liderinden bu tür davranışlar gördüğünde risk alma konusunda daha cesaretli olacaklardır. Örgütte psikolojik güvenlik algısının olması, çalışanların yaratıcılıklarını sergileme yeteneğini 
açığa çıkardığından değerli ve önemli bir olgudur. Bu sebeple örgüt içerisinde psikolojik güvenlik ortamı oluşturulduğunda, çalışanların verimliliği artarak daha iyi performans elde etmeleri sağlanabilir.

$\mathrm{Bu}$ araştırma ile kapsayıcı liderliğin iş performansı üzerindeki etkisinde psikolojik güvenliğin aracılık rolünü tespit etmek amaçlanmıştır. Diğer tüm çalışmalarda olduğu gibi bu araştırmada içerisinde birtakım kısıtlar barındırmaktadır. Bu kısıtlarla ilgili ve gelecek araştırmalara katkıda bulunmak amacıyla bazı öneriler aşağıda belirtilmiştir:

Araştırmada elde edilen verilerin kesitsel çalışma yoluyla toplanmış olması çalışmanın bir kısıtıdır. Kesitsel çalışma, yalnızca bir defa verilen toplandığı ve çalışanın anlık algısına ve psikolojik durumuna göre verilen elde edildiği bir çalışmadır. Bu nedenle verilerin tek zaman halinde toplanması araştırmanın kısıtlarından birisidir.

$\mathrm{Bu}$ araştırmanın yalnızca bir devlet üniversitesinde çalışan akademik personellere uygulanan anketin çıktılarını yansıtması çalışmanın diğer bir kısıtıdır. Bu araştırmanın verileri ile elde edilen çıktıların daha fazla genellenebilmesi amacıyla gelecekte yapılabilecek çalışmaların liderlik davranışının ve iş performansının daha baskın olduğu özellikle hizmet sektörlerinde gerçekleştirilmesi daha geniş bir çerçeve oluşturabilir.

$\mathrm{Bu}$ araştırmada kapsayıcı liderlik ile iş performansı arasındaki ilişkide psikolojik güvenliğin aracılık rolü incelenmiştir. Analizler sonucunda kısmi bir aracılık etki tespit edilmiştir. Gelecekte yapılabilecek çalışmalarda kapsayıcı liderlik ile iş performansı arasındaki ilişkiye etki edebilecek farklı aracı değişkenlerin belirlenmesiyle tam aracılık etki gözlenebilir.

Araştırmanın örnekleminde sadece akademik personeller yer almaktadır. Araştırmamızın modelinde ya da benzer yapıdaki modellerde, akademik personellerin yanı sıra üniversitede çalışan tüm personelin (memur, teknisyen, güvenlik, işçi vb.) örnekleme dahil edilmesi daha faydalı sonuçlar ortaya koyabilir.

Bu çalışmada liderlik stillerinden sadece kapsayıcı liderlik ele alınmıştır. Gelecekteki araştırmacılar, kapsayıcı liderliğe ek olarak diğer liderlik stillerinden bir ya da birkaçını modele entegre ederek liderlik tarzları arasında kıyaslamalar yapabilir. 


\section{KAYNAKÇA}

AbuAlRub, R. F. (2004). Job stress, job performance, and social support among hospital nurses. Journal of Nursing Scholarship, 36(1), 73-78.

Adapa, S. ve Sheridan, A. (2018). Inclusive leadership: Negotiating gendered spaces (1rd ed.). New Delhi: Springer.

Aslan, H. (2019). The mediating role of inclusive leadership in the effect of work engagement on innovative work behavior. OPUS-International Journal of Society Researches, 14(20), 1055-1069.

Ay, F. A. ve Keleş, K. (2017). Etkileşimci ve dönüşümcü liderlik tarzlarının işten ayrılma niyeti ve iş performansı üzerinde etkisi. Gümüşhane Üniversitesi Sağlık Bilimleri Dergisi, 6(4), 193-203.

Ayan, A. (2015). Etik liderlik tarzının iş performansı, içsel motivasyon ve duyarsılaşma üzerine etkisi: Kamu kuruluşunda bir uygulama. Eskişehir Osmangazi Üniversitesi İktisadi ve İdari Bilimler Dergisi, 10(3), 117-141.

Bartram, D. (2005). The great eight competencies: A criterion-centric approach to validation. Journal of Applied Psychology, 90(6), 1185-1203.

Begenirbaş, M. ve Çalışkan, A. (2014). Duygusal emeğin iş performansı ve işten ayrılma niyetine etkisinde kişilerarası çarpıklığın aracılık rolü. Business and Economics Research Journal, 5(2), 109-127.

Boekhorst, J. A. (2015). The role of authentic leadership in fostering workplace inclusion: A social information processing perspective. Human Resource Management, 54(2), 241-264.

Booysen, L. (2014). The development of inclusive leadership practice and processes. B. M. Ferdman ve B. R. Deane (Ed.), In diversity at work: The practice of inclusion içinde (ss. 296-329). San Francisco: Jossey-Bass. 1. bask1.

Bradley, B. H., Postlethwaite, B. E., Klotz, A. C., Hamdani, M. R. ve Brown, K. G. (2012). Reaping the benefits of task conflict in teams: The critical role of team psychological safety climate. Journal of Applied Psychology, 97(1), $151-158$.

Brislin, R. W., Lonner, W. J. ve R.M. Thorndike. (1973). Cross Cultural Research Methods. New York: John-Wiley \& Sons Pub. 1. bask1.

Brueller, D. ve Carmeli, A. (2011). Linking capacities of high-quality relationships to team learning and performance in service organizations. Human Resource Management, 50(4), 455-477.

Burke, C. S., Sims, D. E., Lazzara, E. H. ve Salas, E. (2007). Trust in leadership: A multi-level review and integration. Leadership Quarterly, 18, 606-632.

Carmeli, A., Brueller, D. ve Dutton, J. E. (2009). Learning behaviours in the workplace: The role of high-quality interpersonal relationships and psychological safety. Systems Research and Behavioral Science, 26, 81-98.

Carmeli, A. ve Hoffer Gittell, J. (2009). High-quality relationships, psychological safety, and learning from failures in work organizations. Journal of Organizational Behavior, 30, 709-729.

Carmeli, A., Reiter-Palmon, R. ve Ziv, E. (2010). Inclusive leadership and employee involvement in creative tasks in the workplace: The mediating role of psychological safety. Creativity Research Journal, 22(3), 250-260.

Carmeli, A., Sheaffer, Z., Binyamin, G., Reiter-Palmon, R. ve Shimoni, T. (2014). Transformational leadership and creative problem-solving: The mediating role of psychological safety and reflexivity. Journal of Creative Behavior, 48(2), 115-135.

Chandrasekaran, A. ve Mishra, A. (2012). Task design, team context, and psychological safety: An empirical analysis of R\&D projects in high technology organizations. Production and Operations Management, 21(6), 977-996.

Choi, S. B., Tran, T. B. H. ve Park, B. I. (2015). Inclusive leadership and work engagement: Mediating roles of affective organizational commitment and creativity. Social Behavior and Personality, 43(6), 931-944.

Chrobot-Mason, D., Ruderman, M. D. ve Nishii, L. H. (2014). Leadership in a diverse workplace. D. Day (Ed.), In the oxford handbook of leadership and organizations içinde (ss. 683-708). New York: Oxford University Press. 1. bask1.

Çöl, G. (2008). Algılanan güçlendirmenin işgören performansı üzerine etkileri. Doğuş Üniversitesi Dergisi, 9(1), 35-46.

Derin, N. (2017). İşyerinde kişiler arası güven ile işgören sesliliği arasındaki ilişkide psikolojik rahatlığın aracılık rolü. Yönetim Bilimleri Dergisi, 15(30), 51-68.

Detert, J. R. ve Burris, E. R. (2007). Leadership behavior and employee voice : Is the door really open ? Academy of Management Journal, 50(4), 869-884.

Edmondson, A. (1999). Psychological safety and learning behavior in work teams. Administrative Science Quarterly, 44(2), 350-383.

Edmondson, A. (2003). Managing the risk of learning: Psychological safety in work teams. M. A. West, D. Tjosvold ve K. G. Smith (Ed.), International handbook of organizational teamwork and cooperative working içinde (ss. 255275). Chichester: John Wiley \& Sons Ltd. 1. bask1.

Edmondson, A. C. ve Lei, Z. (2014). Psychological safety: The history, renaissance, and future of an interpersonal construct. Annual Review of Organizational Psychology and Organizational Behavior, 1, 23-43.

Ferdman, B. M. (2014). The practice of inclusion in diverse organizations: Toward a systemic and inclusive framework. B. M. Ferdman ve B. R. Deane (Ed.), In diversity at work: The practice of inclusion içinde (ss. 3-54). San Francisco: Jossey-Bass. 1. bask1. 
Gallegos, P. V. (2014). The work of inclusive leadership: Fostering authentic relationships, modeling courage and humility. B. M. Ferdman ve B. R. Deane (Ed.), In diversity at work: The practice of inclusion içinde (ss. 177202). San Francisco: Jossey-Bass. 1. bask1.

Gu, Q., Wang, G. G. ve Wang, L. (2013). Social capital and innovation in R\&D teams: The mediating roles of psychological safety and learning from mistakes. R\&D Management, 43(2), 89-102.

Gündüzöz, İ. (2013). Liderlik kavraminin iki matrisli analizi. Türk İdare Dergisi, 477, 181-204.

Hayes, A. F. (2017). Introduction to mediation, moderation, and conditional process analysis: A regression-based approach. Introduction to Mediation, Moderation and Conditional Process Analysis. New York: The Guilford Press.

Hirak, R., Peng, A. C., Carmeli, A. ve Schaubroeck, J. M. (2012). Linking leader inclusiveness to work unit performance: The importance of psychological safety and learning from failures. The Leadership Quarterly, 23(1), 107-117.

Hollander, E. P. (2009). Inclusive leadership: The essential leader-follower relationship. New York: Routledge.

Hollander, E. P., Park, B. B. ve Elman, B. (2008). Inclusive leadership and leader-follower relations: Concepts, research, and applications. The Member Connector, International Leadership Association, 5, 4-7.

Kahn, W. A. (1990). Psychological conditions of personal engagement and disengagement at work. Academy of Management Journal, 33(4), 692-724.

Kale, E. (2015). Lider desteği ve iş arkadaşları desteğinin iş performansı üzerine etkileri: İş tatmini ve yaşam tatmininin aracı rolü. International Journal of Economic and Administrative Studies, 7(14), 103-119.

Khan, J., Jaafar, M., Javed, B., Mubarak, N. ve Saudagar, T. (2020). Does inclusive leadership affect project success? The mediating role of perceived psychological empowerment and psychological safety. International Journal of Managing Projects in Business, 13(5), 1077-1096.

Kirkman, B. L. ve Rosen, B. (1999). Beyond self-management : Antecedents and consequences of team empowerment. Academy of Management Journal, 42(1), 58-74.

Lai, F. Y., Tang, H. C., Lu, S. C., Lee, Y. C. ve Lin, C. C. (2020). Transformational leadership and job performance: The mediating role of work engagement. SAGE Open, 10(1), 1-11.

Lee, F. (1997). When the going gets tough, do the tough ask for help? Help seeking and power motivation in organizations. Organizational Behavior and Human Decision Processes, 72(3), 336-363.

Li, A. N. ve Tan, H. H. (2013). What happens when you trust your supervisor? Mediators of individual performance in trust relationships. Journal of Organizational Behavior, 34, 407-425.

Lirio, P., Lee, M. D., Williams, M. L., Haugen, L. K. ve Kossek, E. E. (2008). The inclusion challenge with reduced-load professionals: The role of the manager. Human Resource Management: Published in Cooperation with the School of Business Administration, The University of Michigan and in alliance with the Society of Human Resources Management, 47(3), 443-461.

Motowidlo, S. J., Borman, W. C. ve Schmit, M. J. (1997). A theory of individual differences in task and contextual performance. Human Performance, 10(2), 71-83.

Murphy, K. R. (1989). Is the relationship between cognitive ability and job performance stable over time? Human Performance, 2(3), 183-200.

Nembhard, I. M. ve Edmondson, A. C. (2006). Making it safe: The effects of leader inclusiveness and professional status on psychological safety and improvement efforts in health care teams. Journal of Organizational Behavior: The International Journal of Industrial, Occupational and Organizational Psychology and Behavior, 27(7), 941-966.

Nguyen, P. V., Le, H. T. N., Trinh, T. V. A. ve Do, H. T. S. (2019). The effects of inclusive leadership on job performance through mediators. Asian Academy of Management Journal, 24(2), 63-94.

Obaid, H. J. ve Al-Abachee, A. S. F. (2020). The role of inclusive leadership in enhancing the strategic flexibility. International Journal of Psychological Rehabilitation, 24(7), 6766-6776.

Qi, L. ve Liu, B. (2017). Effects of inclusive leadership on employee voice behavior and team performance: The mediating role of caring ethical climate. Frontiers in Communication, 2(8), 1-9.

Randel, A. E., Dean, M. A., Ehrhart, K. H., Chung, B. ve Shore, L. (2016). Leader inclusiveness, psychological diversity climate, and helping behaviors. Journal of Managerial Psychology, 31(1), 216-234.

Randel, A. E., Galvin, B. M., Shore, L. M., Ehrhart, K. H., Chung, B. G., Dean, M. A. ve Kedharnath, U. (2018). Inclusive leadership: Realizing positive outcomes through belongingness and being valued for uniqueness. Human Resource Management Review, 28(2), 190-203.

Rotundo, M. ve Sackett, P. R. (2002). The relative importance of task, citizenship, and counterproductive performance to global ratings of job performance: A policy-capturing approach. The Journal of Applied Psychology, 87(1), 6680.

Schepers, J., De Jong, A., Wetzels, M. ve De Ruyter, K. (2008). Psychological safety and social support in groupware adoption: A multi-level assessment in education. Computers and Education, 51(2), 757-775.

Sigler, T. H. ve Pearson, C. M. (2000). Creating an empowering culture: examining the relationship between organizational culture and perceptions of empowerment. Journal of Quality Management, 5, 27-52.

Sungu, L. J., Weng, Q., Hu, E., Kitule, J. A. ve Fang, Q. (2020). How does organizational commitment relate to job performance? A conservation of resource perspective. Human Performance, 33(1), 52-69. 
Taştan, S. ve İşiaçık, S. (2020). Kurumsal sosyal sorumluluk algısı ve yenilikçi iş davranışları arasındaki ilişkide psikolojik güvenlik algısının rolünün incelenmesi. International Journal of Management and Administration, 4(7), 84-99.

Tett, R. P. ve Burnett, D. D. (2003). A personality trait-based interactionist model of job performance. Journal of Applied Psychology, 88(3), 500-517.

Van Scotter, J. R. (2000). Relationships of task performance and contextual performance with turnover, job satisfaction, and affective commitment. Human Resource Management Review, 10(1), 79-95.

Wang, Y. X., Yang, Y. J., Wang, Y., Su, D., Li, S. W., Zhang, T. ve Li, H. P. (2019). The mediating role of inclusive leadership: Work engagement and innovative behaviour among Chinese head nurses. Journal of Nursing Management, 27(4), 688-696.

Wasserman, I. C., Gallegos, P. V. ve Ferdman, B. M. (2008). Dancing with resistance: Leadership challenges in fostering a culture of inclusion. K. M. Thomas (Ed.), In diversity resistance in organizations içinde (ss. 175-200). New York: Taylor \& Francis Group/Lawrence Erlbaum Associates.1. bask1.

Wuffli, P. A. (2016). Inclusive leadership: A framework for the global era. Switzerland: Springer.

Xiang, H., Chen, Y. ve Zhao, F. (2017). Inclusive leadership, psychological capital, and employee innovation performance: The moderating role of leader-member exchange. DEStech Transactions on Social Science, Education and Human Science, 111-115.

Ye, Q., Wang, D. ve Guo, W. (2019). Inclusive leadership and team innovation: The role of team voice and performance pressure. European Management Journal, 37(4), 468-480.

Yener, S. (2015). Psikolojik rahatlık ölçeğinin türkçe formunun geçerlik ve güvenirlik çalışması. ODÜ Sosyal Bilimler Araştırmaları Dergisi (ODÜSOBİAD), 5(13), 280-305.

Yu, Y. (2019). Impact of inclusive leadership on employees' adaptive performance. In 2019 International Conference on Education Science and Economic Development, Atlantis P, 393-396. 